УДК 82.09.001.06(477)

Розмариця С. А. аспірант кафедри світової літератури та культури імені О. В. Мішукова Херсонський державний університет

\title{
ТЕКСТ І ПІДТЕКСТ ОПОВІДАНЬ ПИЛИПА КАПЕЛЬГОРОДСЬКОГО «ЧЕРВОНОАРМІЕЦЬ» І «ДІД ЯВТУХ»
}

\begin{abstract}
У статті шляхом аналізу оповідань Пилипа Капельгородського «Червоноармієиь» $i$ «Дід Явтух» робимо спробу з'ясувати специфіку художнього осмислення $i$ відтворення світоглядно-естетичної концепиії автора, реконструйованої з урахуванням підтексту.
\end{abstract}

Ключові слова: текст, підтекст, оповідання, образ, конщепція, світогляд.

В статье путем анализа рассказов Филиппа Капельгородского «Красноармееи» и «Дед Явтух» делаем попытку выяснить спеиифику художественного осмысления и воссоздания мировоззренческо-эстетичной концепции автора, реконструированной с учетом подтекста.

Ключевые слова: текст, подтекст, рассказ, образ, концепция, мировоззрение.

In the article we try to find out the specifics of artistic interpretation and reproducing of ideological and aesthetic conception of the author, reconstructed with the subtext, by analyzing of the stories "Red Army soldier" and "Grandfather Yavtuh" by Philip Kapelhorodskiy.

Keywords: text, subtext, story, image, concept, outlook.

Пилип Капельгородський, на думку сучасних дослідників (Л. Бойка, Р. Синька, О. Філатової, В. Щербини), не вважається однією 3 ключових фігур української літератури початку XX ст., але його творчий доробок дає змогу простежити динаміку i зміст перетворень, переорієнтацій, зумовлених суспільними та історичними феноменами, що були характерні для більшості митців цього періоду. В оповіданнях і повістях письменника, 
які довгий час залишалися поза увагою літературознавців, виразно простежується болісний процес переробки відчуття та сприймання світу, підпорядковування художнього мислення диктатові зовні. Загалом, перефразовуючи слова літературознавця О. Філатової, можемо сказати, що в умовах панування ідеологічних формул i стереотипів, легітимізації політичних репресій П. Капельгородський попервах намагався залишатися поза ідеологією, згодом силувалася писати за вимогами офіційно декларованої риторики, часом вдаючись до ідеологічного маркування, щоб прикрити и неблагонадійну двозначність фактів [Філатова 2011 : 117].

Мета нашої розвідки - шляхом аналізу оповідань «Червоноармієць» і «Дід Явтух» Пилипа Капельгородського з’ясувати специфіку художнього осмислення і відтворення світоглядно-естетичної концепції автора, реконструйованої з урахуванням підтексту.

Українська література перших десятиліть XX століття відзначається значним піднесенням естетичних та світоглядних пошуків, водночас - це один 3 найбільш складних та трагічних періодів в історії національної літератури. У другій половині 1920-х років посилюється вплив більшовицької ідеології на літературний процес. Зокрема набуває гострої конфронтації боротьба різних літературних організацій i груп, все безцеремонніше держава втручається в літературно-мистецьке життя, сягає максимального напруження хвиля кримінально-політичної критики та звинувачень. Все частіше художнє значення творів визначається не професійною критикою, а популярність літературного твору залежить не від читача. «Центр ваги був перенесений з літературної специцфіки на моменти позалітературні, які до літератури прямого відношення не мали, а пов'язані були з класом, отже, сочіально-політичною боротьбою, запроваджуваною партією» [Петров 1992 : 47]. Досить влучну характеристику моральній атмосфері, що склалася в країні на той період, подає М. Драй-Хмара у своєму щоденнику: «Але часи, часи! Щоб ніякогісінької тобі опозиції не було! Щоб ніхто не посмів не те, щзо друкувати вільне слово, а навіть думати вільно! Для чого ж напружувати мізки, коли є готова система думання і філософствування? Відкривай 
книжку Карла Маркса й читай. Їж досхочу - страви вистачить на всіх» [Драй-Хмара $1990: 19]$.

Проте навіть у таких політичних умовах, як справедливо зазначає В. Мельник, в Україні тривало національно-культурне піднесення, чинився опір «не лише в жанрах публічистики чи критики, а й естетичним рівнем національної літератури, яка активно демонструвала зрілість художнього слова як змістом, так $і$ формою» [Мельник 1994 : 234]. Одночасно $з$ художнім аналізом найважливіших проблем, що активно розроблялись в другій половині 20 -х років на сторінках української прози (перспективи української нації, індустріального розвитку країни, виховання нової інтелігенції, збереження моральних норм і законів тощо), письменники продовжують вивчати тему громадянської війни.

Прагнення Пилипа Капельгородського ширше й глибше охопити у сатирично-гумористичних творах - фейлетонах, гуморесках, віршахагітках, критичних статтях (що не всі мали мистецьку вартість. - С. Р.) гострі соціальні процеси в українському суспільстві не перекреслює задум художнього осмислення подій недалекого минулого. Письменник переймається ідеєю зобразити людей, що здатні йти на самопожертву заради інших, людей вольових і сильних духом, мужніх і безкорисливих; цільних особистостей, доля яких тісно переплелась із долею народу. Такі образи з'являються в надрукованих у журналі «Наше слово» оповіданнях «Червоноармієць» (1927 р.) і «Дід Явтух» (1928р.), задум яких виник після знайомства 3 трагічною історією учасників оборони Полтави від денікінських військ, викладеної в нарисі газети «Більшовик Полтавщини» (вони ж і стали прототипами майбутніх героїв, лише дію автор переніс зпід Полтави до Лубен. - С. Р.). В оповіданнях П. Капельгородський розгортає складну картину психологічної неоднорідності тогочасного суспільства, виявляе глибокий драматизм, як окремої людини, так і цілого народу.

Обидва твори позначені єдністю проблематики, тематичного комплексу, авторською визначеністю композиції (принцип бінарного 
протиставлення зображеного, романтичний погляд на героя 3 «патетичної висоти»), структурованістю традиційного сюжетно-образного матеріалу, лаконізмом та яскравістю образів. Коло проблем, поставлених автором в оповіданнях: страдницька доля жінки-матері, безпросвітність життя селянбідняків, втягнутих у вир братовбивчої війни, завойовницькі погроми, розперезані хижацькі інтереси - розширюють межі зображених подій i переводять їх із соціальної проблематики у сферу етико-філософських роздумів (саможертовність, збереження індивідуальної та національної гідності й гордості, загальнолюдських цінностей). Механізм утворення сюжетного тексту оповідань «Червоноармієць» і «Дід Явтух» цілком залежить від настанови наратора, добре обізнаного 3 подіями та їх завершенням, тобто фіналом історії, про яку він розповідає. Оповідач інтерпретує слова, жести, вчинки героїв, акцентуючи увагу на прихованих під зовнішніми нашаруваннями внутрішніх порухах душі, психологічних процесах.

Хронотоп оповідань Капельгородського гранично локалізований: зображені події відбуваються під час громадянської війни (точніше, протягом одного-трьох днів), яка в українській літературі 20-х років ХХ століття інтерпретується як «визначний, переломний момент національної історії» [Агєєва 1994 : 62]. Трагедійні епізоди протистояння героїв-супротивників, що неминуче завершуються кривавою розв'язкою, розігруються в обмеженому просторі - за селом, у полі, в тісній селянській хаті. Побудована на опозиції позитивних (своїх, бідняків) і негативних (чужих, пришлих) характерів система персонажів, що уособлюють різні світи, різні способи життя, є носіями різних морально-етичних норм, стає художньою проекцією жорстокого протистояння в Україні - соціального та національного.

В оповіданні «Червоноармієць», виданому 1927 року окремою книжкою під назвою «Червоноармієць Кучеренко», Пилип Капельгородський в об'єктивно-реалістичній тональності, зрідка звертаючись до романтичної стилістики, розповів про жорстоку розправу денікінців над бійцем Андрієм Кучеренком. Прикметно, що в цій історії, 
виокремлюючи політичну орієнтацію персонажів, автор акцентує на ідейній поляризації, в основі якої покладено національне підгрунтя. Скажімо, українські Лубни, Засулля, Солоницю, Піски від «червоних безбожників» звільняють «горбоносі осетини в черкесках $i$ погонах та денікінські офіцери в кубанках $і$ nапахах» [Капельгородський 1982 : 266]. I від «визволителів», і від їхньої політики та вже традиційних методів «захисту» українців, як іронічно завважує оповідач, «запахло «єдиною неділимою». Авторська іронія щодо найманців російської армії поглиблюється шляхом використання мовних характеристик, уведенням у текст двомовних діалогів, що репрезентують, з одного боку, скалічену мову «визволителів», 3 іншого - емоційно-наснажену, 3 характерними виразами й зворотами, мову бідняків-українців:

«-Стой!.. твая-мая панімай?.. Давай бамага...

- Та навіщуож ти гроші тягнеш?.. Калавур! Господин офіцеер, щзо ж изе таке?

- Ти чего тут орьош? Жаловаться?.. Ур, Сосланбек!.. Сщуо!.. Тохта!.. Будет с него, пока ...

- Пожди золотопогонна сволото, ось повернуться намі!..» [Капельгородський 1982 : 266-267].

Контраст між літературною мовою персонажів й зумисне спрощеною побутовою чи покаліченою російською мовою денікінців справляє сильне враження.

Протистояння між червоноармійцем Андрієм Кучеренком, який, стаючи на захист своєї землі, рідної матері, вступив до робітничого загону кіннотників і був зраджений куркулем-односельцем, та білогвардійським офіцером передається в оповіданні через лаконічні діалоги, без заглиблення у внутрішній світ, без оцінок оповідача чи автора. Натуралістичні деталі, показуючи звірячу жорстокість «визволителів» («Арсланов, одрубай йому праву руку.../ Андрій, закривавлений, повис на мотузках, утративши свідомість. Правиця важко гупнула на підлогу. /..Обличчя капітанове перекособочила огидно-хвороблива 
гримаса. В очах горіло божевілля, в куточках губ лопалася дрібними пухирками піна. / ...Капітан нахилився ближче, вдивляючись у перекошене муками обличчя Андрієве. Зібравщи всі сили, той виплюнув згусток крові просто в випещене капітанське обличчя» [Капельгородський 1982 : 272]), у той же час підкреслюють героїзм, силу духу, нескореність Андрія Кучеренка. Перед читачем постає рішуча, тверда характером, горда особистість. Опинившись у складному становищі, герой робить вибір, навіть усупереч своєму серцю (на зраджує своїх товаришів ціною життя коханої Марини. - С. Р.)

Готовність жертвувати для людей усім, не шкодуючи навіть власного життя, притаманна персонажеві оповідання «Дід Явтух», у якому автор із великою художньою силою розповів про жорстоку розправу денікінських солдат над старим сільським дідом-характериником. У цьому творі більш детально виписано характер героя, вмотивовано психологію його вчинку, виразно зафіксовано (вже традиційно для стилю Капельгородського) зовнішні прояви внутрішнього життя - жест, рух, погляд. «Право ци повноваження авторського «голосу» свідомо делегуються оповідачеві, щио встановлюе комунікацію з читачем... та інтерпретує запрограмовану творчу концепцію (зрозуміло, авторську) як продукт власних інтенциій та індивідуального мислення» [Філатова 2011 : 127].

Оповідання будується на чергуванні яскравих, сонячних картин літнього погожого дня, теплого колориту природи з гнітючими, трагічними картинами людської жорстокості, злості та відчуття смерті. Діалоги персонажів переплітаються із ліризованими описами, внутрішніми монологами, невласне прямою мовою, що підсилюють інтонаційну структуру твору, зображають дійсність через індивідуальне сприйняття. Суттєву роль у творі Капельгородського відіграють так звані зовнішні деталі, які увиразнюють внутрішній стан героя, обрамлюють психологічні процеси.

Образ діда Явтуха - характерний, яскраво виражений, схожий на типовий образ козака чи мудрого селянина-господаря. У 86-літнього «дiда пряма, кремезна постать у білій святковій сорочиі та в чистих старовинних, хоч $і$ благеньких, вибійчаних штанях. Довга апостольська 
борода - віником, і очі з-під кудлатих брів світяться, як на великдень, а сиве волосся на голові - кучерями» [Капельгородський 1982 : 275]; «Голова, як молоко, $і$ борода, як у апостола, а очі - ясні спокійні» [Капельгородський 1982 : 281]; «голову держав прямо, й очі йому світилися з-під кудлатих брів, і ласкаві зморики лапками збігалися по обличчю» [Капельгородський 1982 : 284].

«Найпоказнішу» в селі людину 3 мовчазною вдачею односельці вважали за характерника, який ніколи не помилявся у своїх прогнозах, стояв за правду і справедливість. Коли ділили панську землю, відмовився на користь бідніших і немічних; коли німці карали селян за поділене панське добро, взяв провину на себе. На заклики більшовицьких агітаторів до гуртування впевнено відповідав: «...чи в гурті щзось путнього зробиш, чи сам наодиниі, - усе піде в один казанок» [Капельгородський 1982 : 280]. Сенс свого призначення на землі дід Явтух бачив у тому, щоб «тільки недарма прожити». У загрозливій для односельців ситуації він приймає для себе рішення добровільно зізнатися у вбивстві денікінського солдата, тим самим врятувавши від смерті ні в чому неповинних заручників. Мотивація його вчинку - така ж мудра і виважена, як і саме життя діда Явтуха: не можна покарати десять невинних життів, «бо у всіx - дітu». Герой бере на себе весь тягар відповідальності за долю своїх односельців і йде на смерть спокійно.

Цілком очевидно, що герої оповідань «Червоноармієць» і «Дід Явтух» найповніше розкривають світоглядну позицію автора, що полягала у ствердженні саможертовності заради врятування життя інших, а не заради якоїсь ілюзорної ідеї. 3 іншого боку, драматичні історії юного Андрія Кучеренка і старого діда Явтуха підтверджують недосконалість світу, його дисгармонію.

\section{БІБЛІОГРАФІЯ}

Агеєва 1994 - Агеєва В.П. Українська імпресіоністична проза / В. П. Агеєва. - К. : ВІПОЛ, 1994. - 159 с.

Бойко 1983 - Бойко Л. Історико-революційна проза П. Капельгородського / Леонід Бойко. - К. : Наук. думка, 1983. - 231 с. 
Драй-Хмара 1990 - Драй-Хмара М. Щоденник: 1924-1928 / Михайло Драй-Хмара // Слово і час. - 1990. - № 1. - С. 41-44.

Капельгородський 1982 - Капельгородський П. Твори: в двох томах / Пилип Капельгородський. - К. : Вид-во художньої літератури, 1982. - Т. 2. 390 c.

Мельник 1994 - Мельник В. Суворий аналітик доби: Валер'ян Підмогильний в ідейно-естетичному контексті української прози першої половини ХХ ст. / Володимир Мельник. - К., 1994. - 319 с.

Петров 1992 - Петров В. Діячі української культури - жертви більшовицького терору (1920-1940рр.) / Віктор Петров. - К. : Воскресіння, 1992. - 79 c.

Синько 2002 - Синько Р. Лицар: До 120-річчя від дня народження письменника й громадського діяча Пилипа Капельгородського / Ростислав Синько // Сільський Час. - 2002. - №89. - С.8-9.

Філатова 2010 - Філатова О. Український роман 20-30-х років $\mathrm{XX}$ століття: типологія авторської свідомості : монографія / Оксана Філатова. Миколаїв : Іліон, 2010. - 485 с.

Щербина 2002 - Щербина В. Пилип, ватажок ногайців / Володимир Щербина // Вечірній Київ. - 2002. - 20 грудня. - С. 8. 